\title{
Seasonal variations of aerosol size distributions based on long-term measurements at the high altitude Himalayan site of Nepal Climate Observatory-Pyramid (5079 m), Nepal
}

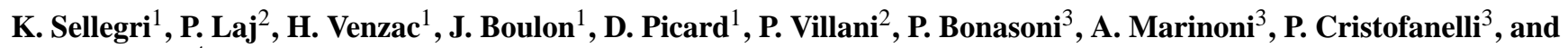 \\ E. Vuillermoz ${ }^{4}$ \\ ${ }^{1}$ Laboratoire de Météorologie Physique, UMR 6016, CNRS/University of Clermont-Ferrand, Clermont-Ferrand, France \\ ${ }^{2}$ Laboratoire de Glaciologie et Géophysique de l'Environnement (LGGE), CNRS/University of Grenoble, Grenoble, France \\ ${ }^{3}$ Institute for Atmospheric Science and Climate (ISAC), CNR, Bologna, Italy \\ ${ }^{4} \mathrm{Ev}-\mathrm{K} 2-\mathrm{CNR}$ Committee, Bergamo, Italy
}

Received: 16 February 2010 - Published in Atmos. Chem. Phys. Discuss.: 9 March 2010

Revised: 29 September 2010 - Accepted: 14 October 2010 - Published: 12 November 2010

\begin{abstract}
The present paper investigates the diurnal and seasonal variability of the aerosol total number concentration, number and volume size distribution between $10 \mathrm{~nm}$ and $10 \mu \mathrm{m}$, from a combination of a scanning mobility particle sizer (SMPS) and an optical counter (OPC), performed over a two-year period (January 2006-February 2008) at the Nepal Climate Observatory-Pyramid (NCO-P) research station, (5079 m a.s.1.). The annual average number concentration measured over the two-year period at the NCO-P is $860 \mathrm{~cm}^{-3}$. Total concentrations show a strong seasonality with maxima during pre-monsoon and post-monsoon seasons and minima during the dry and monsoon seasons. A diurnal variation is also clearly observed, with maxima between 09:00 and 12:00 UTC. The aerosol concentration maxima are mainly due to nucleation processes during the postmonsoon season, as witnessed by high nucleation mode integrated number concentrations, and to transport of high levels of pollution from the plains by valley breezes during the pre-monsoon season, as demonstrated by high accumulation mode integrated number concentrations. Night-time number concentration of particles (from 03:00 to 08:00 NST) are relatively low throughout the year (from $450 \mathrm{~cm}^{-3}$ during the monsoon season to $675 \mathrm{~cm}^{-3}$ during the pre-monsoon season), indicating the of high altitudes background level, as a result of downslope winds during this part of the day. However, it was found that these background concentrations are strongly influenced by the daytime concentrations, as they
\end{abstract}

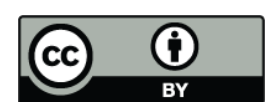

Correspondence to: K. Sellegri (k.sellegri@opgc.univ-bpclermont.fr) show the same seasonal variability. If nighttime concentrations were presumed to be representative of free troposphere (FT)/residual layer concentrations, they would be found to be two times higher than at other lower altitudes European sites, such as the Jungfraujoch. However, BL intrusions might contaminate the free troposphere/residual layer even at this altitude, especially during regional air masses influence. Nighttime measurements were subsequently selected to study the FT composition according to different air masses, and the effect of long range transport to the station.

\section{Introduction}

Rapid economic growth in the Asian regions, in particular China and India, is causing strong air pollution problems that are not confined to urban and sub-urban areas, but involve a large fraction of the Asian continent, hosting over 4 billion people. In particular, anthropogenic emissions of particles and particle precursors from industry, transport and incomplete fossil fuel combustion are rising rapidly (Richter et al., 2005; Ramanathan et al., 2008), leading to great concern about their impact on air quality and climate. It is estimated that air pollution exceeding WHO guidelines causes more than 500000 premature deaths in Asia annually, in particular in the large Asian cities (Cohen et al., 2005). However, air pollution, in particular the particulate fraction, also affects the atmospheric energy budget with significant impacts on regional climates and precipitation dynamics.

This layer of particulate pollution that can be observed also from satellites is often referred to as brown cloud

Published by Copernicus Publications on behalf of the European Geosciences Union. 
(Lelieveld et al., 2001; Nakajima et al., 2007; Ramanathan et al., 2007a, b). Brown clouds generally denote anthropogenic aerosols that not only scatter, but also absorb solar radiation due to black carbon, dust and other absorbing materials. Over the past decade, considerable research investment has begun in Asia, bringing large-scale international and national regional experiments, such as INDOEX, (Indian Ocean Experiment), ACE-Asia (Aerosol-Cloud Experiment Asia) and $\mathrm{ABC}$ (Atmospheric Brown Cloud), studying precursor gases and aerosol. Such experiments have led to a much better assessment of aerosol impact on the atmospheric radiative balance and the development of the Indian monsoon, as well as impacts on agriculture and human health. The water cycle dynamics and surface energy feedback appear to be triggered by aerosol direct effects. (Hansen et al., 2000; Ramanathan et al., 2001). Ramanathan et al (2005) showed that the blocking of solar radiation reaching the surface by aerosol induces Earth surface cooling, leading to a gradual spin-down of the tropical water cycle, and the eventual weakening of the Asian monsoon. Aerosols can, therefore, affect the cloud-radiation feedback, with impacts on land-atmosphere interactions and precipitation in the Indo-Ganges Basin and the Himalayas.

Work performed within INDOEX revealed that this haze layer can be efficiently transported far beyond the source region (Clarke et al., 2002), in particular as far as the high altitude region of the Himalayas. Atmospheric aerosols emitted in the Indian plains and lofted into the mid- and uppertroposphere by thermal winds are efficiently stacked up towards the southern foothills and slopes of the Himalayas, rising to higher altitudes and reaching the Tibetan Plateau.

In order to provide reliable estimates of the impact of particles on air quality and climate, information on source emissions and temporal and spatial variability of their chemical, physical and optical properties, are urgently required. The ABC project of the United Nation Environmental Program (UNEP) has been coordinating a network of stations in Asian countries on the Indian and Pacific oceans, with the aim of monitoring the extension and composition of atmospheric brown clouds. Most of these stations are located in coastal or island environments, providing little information on the aerosol concentrations in the higher Himalayan mountain environments. Lack of direct information on the nature of aerosol particles sampled in the high altitude regions is, therefore, still limiting the more precise quantification of aerosol impact on the atmospheric energy budget, especially far from emission sources.

The atmospheric impact of this changing area is, in fact, best evaluated by long term measurements, located at a background site not influenced by local pollution. While pollutants are released from different sources with a high time variability, and interact with each other in a complex manner, observations of seasonal and diurnal pollutant variations at a remote high altitude site provides insight on the horizontal and vertical extent of the anthropogenic influence on the broader regional and global atmospheric scale.
Particle size distribution and number concentration of are among the major aerosol parameters constraining (1) aerosol radiative forcing, as they directly relate to the optical properties of an aerosol population, (2) cloud forming capacity of an aerosol population, as they directly relate to the number of available cloud condensation nuclei (CCN), and (3) the health impact of aerosols, as they provide useful information on the lung-penetrating fraction of the aerosol population. An accurate knowledge of long-term particle number and size variability is therefore clearly relevant to aerosol and climate sciences. In particular, very little information exists to date from Asian remote sites, especially for the high altitude regions of the Himalayas.

Aerosol number size distributions have been characterized at other high altitude stations, by Raes et al. (1997) at the Izana station (2373 meters above sea level (m a.s.l.)), Weingarter et al. (1999) and Nyeki et al., 1998 at the Jungfraujoch station in the Swiss Alps, (3450 m a.s.l.) and, more recently, at Mt Norikura (2770 m a.s.1.), Japan (Nishita et al 2007), at the top of Mount Lemmon (2790 m) in Arizona, USA (Shaw 2007), puy de Dôme, central France (1465 m) (Venzac et al., 2009) and Monte Cimone, Italian Northern Apennines (2165 m) (Marinoni et al., 2008). The only information available for Asia concerns Mt Waliguan (3816 m), inland China (Kivekäs et al., 2009) and the study of Komppula et al. (2009) at the Mukteshwar station $(2180 \mathrm{~m})$, in Northern India. Of all the studies listed above, only a few report long-term records allowing for seasonal variation analysis.

The objective of the present paper is therefore to report and analyze a unique data set of aerosol size and number concentration measured at the 5079 ma.s.l. Himalayan Nepal Climate Observatory-Pyramid (NCO-P) site over a two-year period. The measurements are used to characterize aerosol variability far from local sources and, in particular, its seasonal variability. Additional classification using air mass back-trajectories is subsequently used to provide a robust statistical description of aerosol physical properties.

\section{Site description and instrumental set-up}

The NCO-P (Nepal., $27.95^{\circ} \mathrm{N}, 86.82^{\circ} \mathrm{E}$ ), is described in detail by Bonasoni et al. (2010). Here, only information relevant to the scope of the present paper will be provided. NCO$\mathrm{P}$ is located in the Khumbu valley at $5079 \mathrm{~m}$ a.s.l., ideally situated between China and India to study the long-range and regional transport of anthropogenic pollutants. The station is equipped to perform continuous measurements of chemical (organic and inorganic, soluble and insoluble), physical (mass and number size distribution) and optical (absorption and scattering coefficients) properties of aerosol. The submicron aerosol size distribution is measured with the scanning mobility particle sizer (SMPS) technique using a TSI Inc. 3010 Condensation Particle Counter and a custom-made Differential Mobility Analyzer (Villani et al., 
2008) assembled, tested and quality controlled according to EUSAAR recommendations (http://www.eusaar.net/). The SMPS size distributions were acquired from $10 \mathrm{~nm}$ to $650 \mathrm{~nm}$ with a two-minute time resolution. Calibration of the SMPS is performed once a year during the annual station maintenance campaign, using calibrated latex spheres (from 100 to $400 \mathrm{~nm}$ ) directly nebulized into the SMPS inlet. Good agreement between expected and measured particle sizes has been consistently found since the beginning of operations. Measurements were performed with a two-minute resolution from January 2006 to February 2008 without instrumental failures except during the summer 2006 (6 August to 17 September).

Supermicron size distributions were acquired with an optical particle counter (OPC) GRIMM 190 over the diameter range $0.25-32 \mu \mathrm{m}$. After comparing the SMPS and OPC size distributions on their overlapping diameters, it was decided to discard the first four channels of the OPC, on which SMPS and OPC diverged the most. SMPS and Grimm 190 size distributions were merged, using the SMPS size distributions up to $400 \mathrm{~nm}$ and Grimm data beyond this size. Number size distributions were fitted to a sum of log-normal distributions. Three modes were usually found, the first one having a mean geometric diameter lower than $30 \mathrm{~nm}$ (hereafter referred to as nucleation mode), the second one has a geometric mean diameter being comprised between 30 and $85 \mathrm{~nm}$ (Aitken mode), and the third mode has a geometric mean diameter larger than $85 \mathrm{~nm}$ between (accumulation mode). Because the various impacts of particles (direct and indirect radiative impact, deposition on the snow surface, etc.) should be calculated under the local atmospheric conditions, concentrations are given, unless mentioned otherwise, at the local pressure, whose seasonal average varies between $550 \mathrm{hPa}$ (dry season) and $553 \mathrm{hPa}$ (monsoon and post-monsoon seasons).

The sampling of aerosols is performed using a $\mathrm{PM}_{2.5}$ head inlets (flow rate $1 \mathrm{~m}^{3} \mathrm{~h}^{-1}$ ) for the SMPS and a Total Suspended Particle (TSP) head for the optical particle counter $\left(0.018 \mathrm{~m}^{3} \mathrm{~h}^{-1}\right)$. There is a possibility that particles are inadequately sampled through the $\mathrm{PM}_{2.5}$ head inlet during cloudy conditions. RH was measured at the station continuously, and can give indications on the frequency of occurrence of clouds at the level of the station. At the PDD station, where LWC was measured simultaneously to RH, it was found that when the LWC is higher than 0.05 , the RH sensor is indicating higher values than $98 \%$ for $95 \%$ of the time (unpublished data). The same comportment was observed over a two months period at the NCO-P when the web-cam images were analyzed in comparison to the values of the RH sensor. Hence, based on the RH sensor, it was found that the station at maximum $17 \%$ of the time in cloud on average. This effect can lower the concentration of particles larger than $100 \mathrm{~nm}$ (usual activation diameter) at maximum by $17 \%$ on average, and she should keep it in mind.
Particles are dried before entering the SMPS, using a diffusion dryer filled with silica gel. In the OPC, the aerosol particles are not dried prior to sampling, but the temperature differences between the ambient air and the shelter air is always higher than a few degrees so the sampling RH is always lower than $50 \%$.

As explained in detail by Bonasoni et al. (2010), meteorological conditions at the station are driven on the seasonal scale by the monsoon activity, and on the diurnal scale by thermal wind developments in the valley. On an annual time scale, the site is under the influence of the Indian summer monsoon from the beginning of June until September, while the winter season lasts from December to February (Bollasina et al., 2002). Intermediate seasons are defined as the pre-monsoon season (March-May) and post-monsoon season (October-November). Onset and offsets are described in detail with their year to year variability for the 2006-2008 period in Bonasoni et al. (2010). The station is located at the uppermost point of a valley, with mountain and valley winds whose strength varies according to the time of the day and the season. A strong valley wind (S-SW) prevails during the afternoon, and a weaker down-slope breeze prevails during night-early morning. Compared to the other seasons, the monsoon season is characterised by a weaker mountain breeze and lower diurnal variations of temperature, due to the frequently cloudy conditions occurring at the measurement site (Bollasina et al., 2002; Bonasoni et al., 2010). As a result of valley wind circulation, aerosol particles transported from lower altitudes in the valley are expected to reach the measurement site during the day, and free tropospheric aerosol particles to be transported there during the night.

\section{Results}

\subsection{Seasonal variation of total number concentration}

\subsubsection{Seasonal variability analysis}

Integration of the SMPS and OPC size distributions gives access to the total number concentration of particles from $10 \mathrm{~nm}$ up to $32 \mu \mathrm{m}\left(\mathrm{CN}_{\text {tot }}\right)$. The annual average number concentration measured over the two-year period at NCO$\mathrm{P}$ is $860 \pm 55 \mathrm{~cm}^{-3}$. The variability of $\mathrm{CN}_{\text {tot }}$ during the considered observation period is shown Fig. 1. In the figure, the record is split between daytime (hereinafter defined from 10:00 to 18:00 Nepal Standard Time (NST)) and nighttime concentrations (from 03:00 to 08:00 NST). The monthly mean concentrations of particles at NCO$\mathrm{P}$ during daytime vary from $840 \mathrm{~cm}^{-3}$ (monsoon season) to $1500 \mathrm{~cm}^{-3}$ (pre-monsoon season), with an averaged yearly concentration of $1300 \mathrm{~cm}^{-3}$. During nighttime, concentrations are lower, varying from $450 \mathrm{~cm}^{-3}$ (monsoon season) to approximately $675 \mathrm{~cm}^{-3}$ (pre-monsoon season), with 


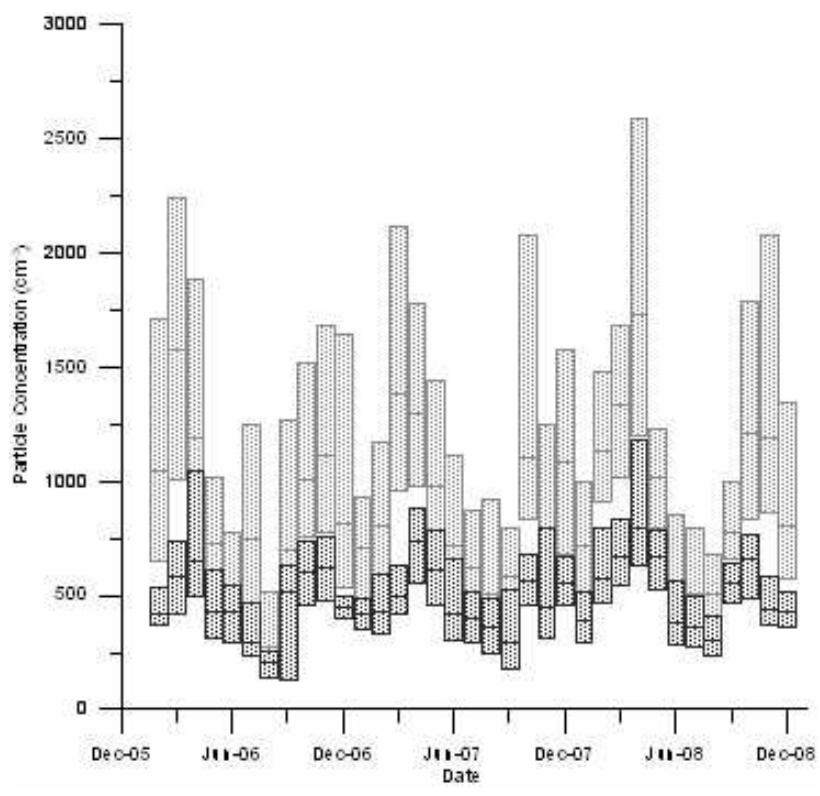

Fig. 1. Monthly median, 25ile and 75ile of the total particle number daytime (light blue) and nighttime (dark blue) concentrations.

an averaged concentration of $580 \mathrm{~cm}^{-3}, 50 \%$ lower than daytime concentrations regardless of season.

$\mathrm{CN}_{\text {tot }}$ shows two clear yearly maxima, observed for both daytime and nighttime concentrations: one during the premonsoon season, the other during the post-monsoon season. The seasonal variations are obviously different from those observed in more temperate regions, where only one maximum is often observed during the summer period, due to a higher frequency of boundary layer air masses reaching the sites during warm seasons (Nyeki et al, 1998; Marinoni et al., 2008; Venzac et al., 2009).

The variability of the monthly mean and the day/night difference are the result of several factors. The first is related to the variability of the regional PBL dynamics characterizing the Himalayan foothills, which does not reach high altitude sites with the same frequency throughout the year, the second is the seasonality of the regional PBL concentrations themselves, and the last is the occurrence of new particle formation (NPF) events, which might be promoted by thermal wind circulation and high altitude photochemistry.

Particle nucleation events at NCO-P have been discussed in detail by Venzac et al. (2008), showing that NPF events take place very frequently at NCO-P and throughout the valley. Such events are favoured by sunny conditions and take place in the morning hours (09:00-11:00 NST) simultaneously with the local wind shift from downslope to upslope conditions. This effect clearly contributes to increasing daytime $\mathrm{CN}_{\text {tot }}$ concentrations with respect to nighttime. Because the frequency and intensity of NPF events change according to season, the monthly averaged record is unevenly affected by this feature. The seasonality of the NPF event frequency shows high frequency during the post-monsoon season, and also, surprisingly, during the monsoon season (Venzac et al., 2008). The contribution of NPF events to the total aerosol number concentration will be further discussed in Sect. 3.2., dealing with size distributions

Moreover, upslope thermal winds bringing air from the polluted Nepal plains (Panday et al., 2009; Bonasoni et al., 2010) also contribute to higher concentrations during daytime. Our observations are in agreement with those of Komppula et al. (2009), who observed at Mukteshwar station, located in the Indian foothills of the Himalayas, the lowest particle number concentrations during the rainy season and highest ones during the pre-monsoon season. The main reason for the low monsoon total number concentrations is the very efficient washout of particles by rain before they reach the measurement station. This effect would best be observed on the accumulation mode particles. In fact, Nishita et al. (2007) observed at Mt Norikura, in Japan, a clear decrease of the number concentration of particles in the accumulation mode, linearly correlated with the cumulative precipitation amounts during the $24 \mathrm{~h}$ preceding the sampling time. The decrease in particle number concentrations of the accumulation mode were found to be mostly explained by incloud scavenging at Mt Norikura, and could therfore be one of the causes of the low concentrations observed in the present study during the monsoon season. It cannot be excluded that additional, although some losses result from inadequate sampling of cloud drops during cloud formation at the station, since the SMPS measurement line is not equipped with a whole air inlet. During the monsoon season, this effect could artificially decrease the accumulation mode number particles by $20 \%$ if all of them are activated into cloud droplets (considering the activation diameter is usually around $100 \mathrm{~nm}$ ). The good agreement in seasonal variations of the total particle concentrations between the NCO-P and Mukteshwar stations may indicate an efficient transport of pollution aerosols from the valleys to extremely high altitudes. Regional pollution aerosols are mostly found in the accumulation mode, and a detailed investigation of their contribution to the total aerosol number concentrations will be performed to confirm this hypothesis for the pre-monsson season in Sect. 3.2.

The last effect is linked to atmospheric dynamics. The development of the PBL height over the Indian plains is favoured during warm periods, and is minimum during the cold seasons. When the PBL height is low, it less frequently reaches high altitude sites, where minimum aerosol concentrations are everywhere recorded during winter. In fact, relatively low particle concentrations were also observed during the cold dry season. Contrary to European high altitude stations, however, the summer period (monsoon) is not characterized by the highest concentrations. In fact, over South Asia, PBL height has a pronounced seasonal variation, with highest values during the pre-monsoon (e.g. Vernekar et al., 2003), which could also partly explain the high pre-monsoon total number concentrations observed at NCO-P. 


\subsubsection{Comparisons with total number concentrations at other altitude sites}

Yearly averaged particle concentrations can be compared to other high altitude sites. Because the ambient sampling pressures can be very different from one altitude station to the other, we chose to correct all concentrations to correct all concentrations to the sea level pressure, i.e. $1013 \mathrm{hPa}$, in the Sect. 3.1.2. After pressure correction, the NCO-P average median concentration is $1580 \mathrm{~cm}^{-3}$. From measurements performed in the foothills of the Indian Himalayas at the Mukteshwar station (2180 ma.s.1.), Komppula et al. (2009) reported an average particle (10 $800 \mathrm{~nm}$ ) number concentration more than two times higher $\left(3480 \mathrm{~cm}^{-3}\right)$ than NCO-P. Still on the Asian continent, at Mount Waliguan (3816 m a.s.l.), the yearly median total concentrations are very similar to those sampled at Mukteshwar, reaching $3280 \mathrm{~cm}^{-3}$ (Kivekäs et al., 2009). The lower height of these stations compared to NCO-P implies that the PBL air is sampled more frequently, influencing the average yearly concentrations. In addition, both stations are also closer to major pollutant source areas.

In Europe, yearly averaged CNtot seem to be ubiquitously lower at different mountain sites (i.e. possibly in the free troposphere). At Jungfraujoch the annual average number concentration of particles $(10-750 \mathrm{~nm})$ is $900 \mathrm{~cm}^{-3}$ (Weingartner et al., 1999), while at the puy de Dôme (1465 ma.s.l.), whose lower altitude permits PBL air to be sampled more frequently, the yearly average concentration is $3080 \mathrm{~cm}^{-3}$. The data sets of European sites are usually subdivided into a nighttime sampling period, during which the high altitude sites are presumably dominated by free troposphere conditions, and a daytime sampling period during which a direct influence of the PBL can be observed.

The average night-time (03:00-08:00 NST) yearly concentration measured at NCO-P is $1050 \mathrm{~cm}^{-3}$. It was calculated from Komppula et al. (2009) that the average seasonal concentration at night varies from about $1500 \mathrm{~cm}^{-3}$ during the monsoon season to about $4500 \mathrm{~cm}^{-3}$ during the pre-monsoon season, with a yearly average of $2600 \mathrm{~cm}^{-3}$ at the Mukteshwar station at $2180 \mathrm{~m}$ a.s.l. Such values are still significantly higher than the ones measured at NCO-P, but the Mukteshwar station, despite its high altitude, seems to be frequently located within the PBL, even at night (Hyvärinen et al., 2009). At puy de Dôme, CNtot varies between $700 \mathrm{~cm}^{-3}$ during winter to $2700 \mathrm{~cm}^{-3}$ during summer for nighttime conditions, while the yearly nighttime concentration is $1400 \mathrm{~cm}^{-3}$. At this altitude, this site is not fully in the free troposphere at night, but still often in the residual layer (Venzac et al., 2009). At Jungfraujoch, nighttime CNtot is $461 \mathrm{~cm}^{-3}$ (Nyeki et al., 1998), which is roughly two times lower than the concentrations measured at NCO-P, despite its lower altitude. At the top of Mt. Lemmon, Arizona, Shaw (2007) measured a mean particle number concentration of $1465 \mathrm{~cm}^{-3}$ in the size range $(12-390 \mathrm{~nm})$ during late winter and spring (February-May) at night time, when conditions are expected to represent the free troposphere. This average concentration is significantly higher than the one reported here for NCO-P, although similar to those reported for puy de Dôme. The relationships between stations, even when presumably mainly located in the free troposphere, are not straightforward when considering only total number concentrations. It can be said, however, that altitude is not the only factor influencing the CNtot background in the free troposphere. The analysis of the size distributions will contribute to a better understanding of these connections, and to a better understanding of the seasonal variations observed in the total number concentrations.

\subsection{Daily variation of size distributions}

Geometric mean diameters calculated from the average hourly size distributions are reported Table 1 . According to the different seasons and night/day data sorting, the number size distributions peak at $15-27 \mathrm{~nm}$ for the nucleation mode, $35-68 \mathrm{~nm}$ for the Aitken mode and $110-200 \mathrm{~nm}$ for the accumulation mode particles.

While Komppula et al. (2009) report size distributions dominated by the accumulation mode except during the rainy season, at NCO-P a very important presence of the Aitken and nucleation modes is observed, during both valley and mountain breezes, except during the pre-monsoon season, when the accumulation mode dominates. Consequently, except for the pre-monsoon season, it is concluded that PBL aerosols might only partly contribute to the aerosol load sampled NCO-P.

As detailed in Venzac et al. (2008), the diurnal variation of the aerosol number concentration shows a clear increase onset around 09:00 NST for all seasons, which can lead to a multiplication by 2 to 4 of the concentrations. The resulting total number concentrations are found to be surprisingly high for this high altitude, with a mean hourly value peaking at $2000 \mathrm{~cm}^{-3}$ during the post-monsoon season at noontime (Fig. 2). The size of the particles responsible for this increase in concentrations appears to be the smallest detectable by the SMPS $(10 \mathrm{~nm})$ at the onset of the increase, with a growth in size later in the day, up to $50 \mathrm{~nm}$, i.e. the nominal size of the Aitken mode found at night in the free troposphere in the area. NPF has been identified as one of the processes responsible for the aerosol number concentration increase during the day (Venzac et al., 2008), and seems to be responsible for the total particle concentration increase observed during the post-monsoon season (the nucleation mode particles increase comprise around $85 \%$ of the total number concentration increase), as also suggested by nucleation mode integrated concentrations three times higher than during the dry season (Table 1). In fact, NPF frequency was also found to be high during the post-monsoon season. 
Table 1. Daytime and nighttime median integrated number concentrations and median geometric mean diameters for the nucleation, Aitken and accumulation modes and total number concentration during different seasons.

\begin{tabular}{lllll}
\hline $\mathrm{N}\left(\mathrm{cm}^{-3}\right)$ (day/night) & Dry Season & Pre-monsoon & Monsoon & Post-monsoon \\
\hline Nucleation & $485 / 220$ & $535 / 240$ & $\mathrm{nd} / \mathrm{nd}$ & $1050 / 370$ \\
Aitken & $465 / 225$ & $465 / 240$ & $620 / 304$ & $380 / 261$ \\
Accumulation & $150 / 25$ & $480 / 195$ & $220 / 143$ & $120 / \mathrm{Nd}$ \\
Total & $1100 / 470$ & $1480 / 675$ & $789 / 447$ & $1550 / 630$ \\
$D p_{N}(\mathrm{~nm})($ day/night) & & & & \\
Nucleation & $15 / 22$ & $18 / 27$ & $\mathrm{Nd} / \mathrm{Nd}$ & $17 / 22$ \\
Aitken & $68 / 63$ & $65 / 64$ & $35 / 40$ & $65 / 65$ \\
Accumulation & $180 / 200$ & $150 / 135$ & $130 / 110$ & $150 / \mathrm{Nd}$ \\
\hline
\end{tabular}

Table 2. Daytime and nighttime median integrated volume concentrations in the accumulation and coarse modes and total volume concentration during different seasons. Geometric Mean volume diameter of the accumulation and coarse modes during different seasons.

\begin{tabular}{llllll}
\hline \multicolumn{2}{c}{$\mathrm{V}\left(\mu \mathrm{m}^{3} \mathrm{~cm}^{-3}\right)$} & Dry Season & Pre- monsoon & Monsoon & Post- monsoon \\
\hline \multirow{2}{*}{ Day } & Accumulation & 1.46 & 2.51 & 0.7 & 1.16 \\
& Coarse & 2.15 & 5.5 & 1.67 & 1.58 \\
\multirow{4}{*}{ Night } & Total & 3.61 & 8.01 & 2.37 & 2.74 \\
& Accumulation & 0.41 & 1.47 & nd & 0.42 \\
& Coarse & 0.42 & 2.76 & 1.27 & 0.26 \\
\multirow{5}{*}{ Dpv (nm) } & Total & 0.83 & 4.23 & 1.27 & 0.68 \\
Day & Dry Season & Pre-monsoon & Monsoon & Post-monsoon & \\
\multirow{2}{*}{ Night } & Accumulation & 409 & 335 & 307 & 411 \\
& Coarse & 3683 & 3794 & 3520 & 3738 \\
& Accumulation & 373 & 436 & nd & 380 \\
& Coarse & 3184 & 3529 & 3547 & 2988 \\
\hline
\end{tabular}

Nucleation mode particles are suspected to form along the valley and up to $5079 \mathrm{~m}$ a.s.l., due to the transport of precursor gases reacting by photochemistry. Komppula et al., 2009 instead found that nucleation mode particle concentrations at Mukteshwar were highest during the pre-monsoon season. Because Mukteshwar is located at the foot of the Indian Himalayas, nucleation mode particles produced at lower altitudes, with highest efficiency during spring, can be transported to NCO-P, where they are sampled after a continuous growth up to Aitken size. At NCO-P, it was shown that nucleation was a high altitude process (Venzac et al., 2008), which seems to be triggered by valley breezes, and not transported by valley breezes. Hence NPF at NCO-P does not coexist with NPF at lower altitudes.

Although NPF occurs only during the day, the nucleation mode integrated concentrations remain high during the night. This could indicate that nucleation processes occurring during the uplift of air masses from the valley are feeding the free troposphere during the day, involving higher concentrations also at night in the FT during the post-monsoon season. Recent work by Spracklen et al. (2010) shows, in fact, that the seasonal $\mathrm{CN}$ cycle observed at field stations worldwide is better simulated by including particle formation mechanisms than by increasing the number emission from primary sources.

The causes of the high particle concentrations observed during the pre-monsoon season are various. Indeed, the nucleation mode integral concentrations are not as high during the pre-monsoon season than during the post-monsoon season. The reason why nucleation is promoted during the postmonsoon season rather than the pre-monsoon season, which exhibits the same level of radiation, is probably due to the lower accumulation mode integrated concentrations detected by the SMPS, and hence a lower condensational sink promoting nucleation (Kerminen et al., 2001) during the postmonsoon season. It is here confirmed that the pre-monsoon season is not favourable to nucleation, in view of the fact that the highest volume concentrations are calculated for that season (Table 2). It was found that the high pre-monsoon number concentrations are mainly attributed to high accumulation mode integral number concentrations, which are significantly higher than during the dry season (Table 1). In fact, during the pre-monsoon season, the high particle number concentrations observed in the late afternoon are partly 

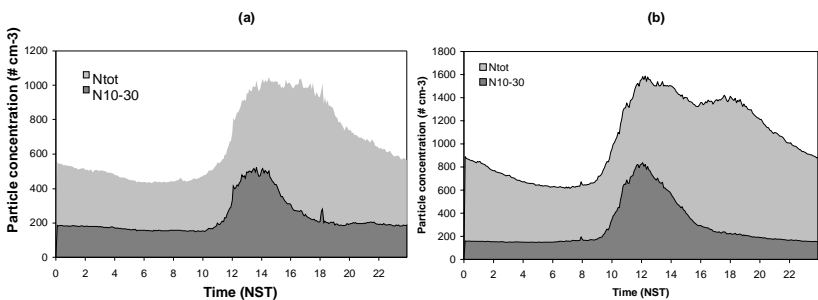

Fig. 2. Mean diurnal variation of the aerosol total number concentration Ntot (light grey area), and 10-to-30 nm integrated number concentrations N10-30 (dark grey) averaged over the whole measurement period for the (a) dry season, (b) pre-monsoon season, (c) monsoon season and (d) post-monsoon season.

due to the transport of accumulation mode particles (about $150 \mathrm{~nm}$ ). On Figure 2, a clear secondary maximum of total number concentrations is observed around 18:00 NST, due to the increase of particles larger than $30 \mathrm{~nm}$. Accumulation size particles are evidences of long-range transport, particles of this size having been formed and later on transformed by cloud processing, or aged by photochemical formation of particulate matter. Black carbon, a tracer for combustion processes, was observed to increase at the same time as the accumulation mode particle number concentrations during the pre-monsoon season. Moreover, it was also found in the present study that the coarse mode particle volume increased during the pre-monsoon season (Table 2), as also shown by Marinoni et al. (2010). The transport of accumulation and coarse mode particles is best illustrated by the volume size distributions, shown in Fig. 3, where it is very clear that accumulation mode particle volume increases during the late afternoon hours, especially during the pre-monsoon season. The same is observed for coarse mode particle mass, representative of dust, for all seasons except for the monsoon (Marinoni et al., 2010). During the pre-monsoon season, the transport of regional/long-range polluted aerosols to the high glacier-altitudes in the Himalayas could have significant impacts on the local radiative balance (Marcq et al., 2010; Yasunari et al., 2010).

During the monsoon season, the coarse mode particle volume increases during nighttime. This observation is probably due to the cloud droplet scavenging of large particles by clouds during the day, which form more frequently at the station during daytime hours during the monsoon season, favored by thermal circulation and forced convection. Aerosol scavenging by cloud droplets is also clearly seen on the daytime accumulation mode particle integrated volume concentrations, which are lowest during the monsoon season. However, accumulation mode integrated number concentrations remain reasonably high during the monsoon season, compared to the other seasons, possibly because only the larger particles of the accumulation mode are activated in cloud droplets, or because new accumulation mode particles are generated along the valley trajectory path after the
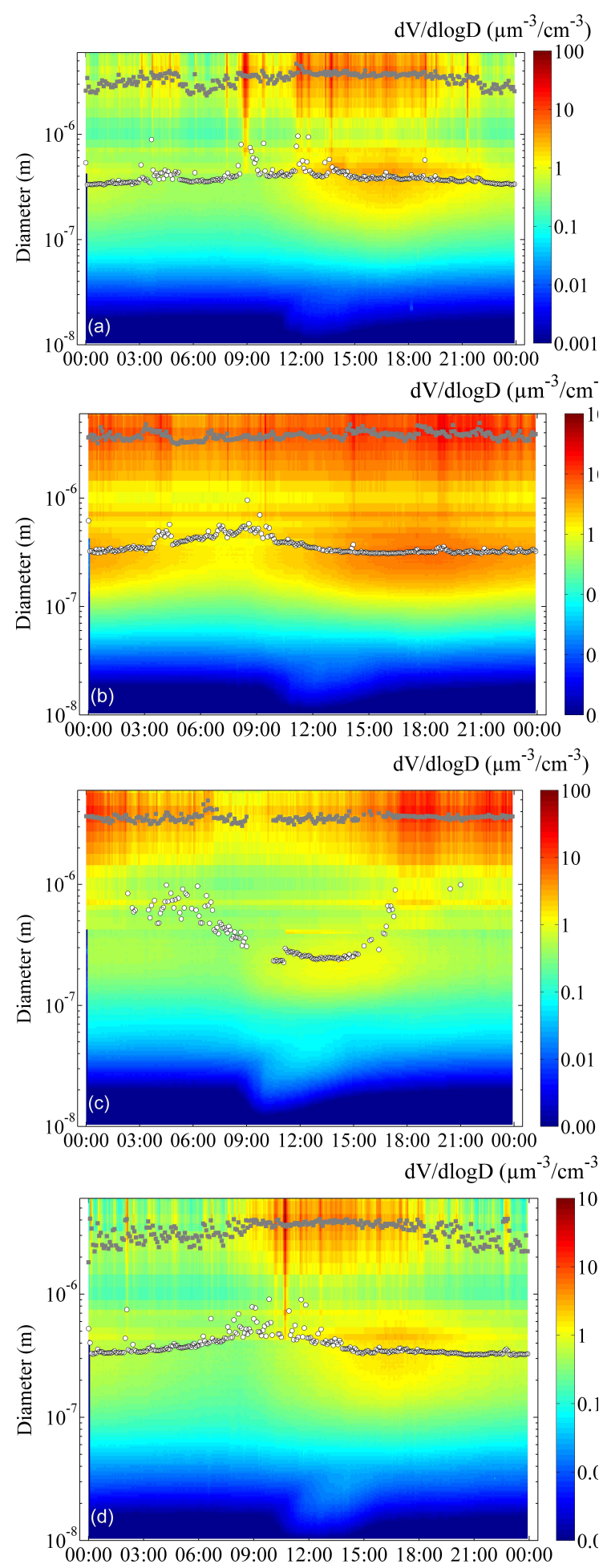

Fig. 3. Mean diurnal variation of the aerosol volume size distribution detected from 10 to $6000 \mathrm{~nm}$ and accumulation (white dots) and coarse (grey squares) diameter mode fitted on aerosol volume size distribution, averaged over the whole measurement period for the (a) dry season, (b) pre-monsoon season, (c) monsoon season and (d) post-monsoon season. 
Table 3. Seasonal cluster frequency and number (in parenthesis). See text for the air mass origin type description.

\begin{tabular}{lllll}
\hline Cluster & Pre-monsoon & Monsoon & Post-monsoon & Dry season \\
\hline SW-AP & $8.98 \%(36)$ & - & $10.18 \%(17)$ & $18.02 \%(60)$ \\
SW-AS & $11.97 \%(48)$ & - & $7.78 \%(13)$ & $8.11 \%(27)$ \\
SW-BG & - & $22.31 \%(114)$ & - & - \\
W-NA & $29.85 \%(120)$ & - & $18.56 \%(31)$ & $47.15 \%(157)$ \\
W-EU & $6.2 \%(25)$ & - & - & - \\
W-ME & $19.4 \%(77)$ & $3.91 \%(20)$ & $37.13 \%(62)$ & $6.91 \%(23)$ \\
REG & $23.95 \%(96)$ & $73.8 \%(377)$ & $26.35 \%(44)$ & - \\
\hline
\end{tabular}

Table 4. Geometric Mean number diameter of the Nucleation, Aitken and accumulation modes during different seasons segregated into air mass origins.

\begin{tabular}{llllll}
\hline$D p_{N}$ & & Dry & $\begin{array}{l}\text { Pre- } \\
\text { monsoon }\end{array}$ & Monsoon & $\begin{array}{l}\text { Post- } \\
\text { monsoon }\end{array}$ \\
\hline $\begin{array}{llllll}\text { Nucleation } \\
\text { mode }\end{array}$ & W-NA & 25 & 30 & - & 23 \\
& SW-AS & 20 & 30 & - & 32 \\
& SW-AP & 22 & 29 & - & 25 \\
& W-EU & 19 & 24 & - & - \\
& W-ME & 25 & 28 & 31 & 32 \\
& Reg & - & 30 & - & 25 \\
Aitken & BG & - & & - & \\
mode & W-NA & 56 & 64 & - & 40 \\
& & & & & \\
& SW-AS & 56 & 65 & - & 53 \\
& SW-AP & 54 & 64 & - & 53 \\
& W-EU & 63 & 70 & - & - \\
& W-ME & 65 & 61 & 73 & 60 \\
& Reg & - & 66 & 46 & 53 \\
Accumulation & BG & - & - & 39 & - \\
mode & W-NA & 200 & 125 & - & 135 \\
& & & & & \\
& SW-AS & 200 & 135 & - & 125 \\
& SW-AP & 200 & 135 & - & 125 \\
& W-EU & 200 & 135 & - & - \\
& W-ME & 200 & 120 & 160 & 125 \\
& Reg & - & 125 & 180 & 110 \\
& BG & - & - & 180 & - \\
\hline
\end{tabular}

atmosphere is washed out. Such hypotheses are confirmed by the lower geometric mean diameter of the accumulation mode particles during the monsoon season (Table 2). The monsoon is the only season for which nighttime concentrations are of the same order as the daytime concentrations. Again, this is likely due to daytime preferential cloud scavenging compared to nighttime and to the fact that, following Ueno et al. (2008), it is possible that during the monsoon, the nighttime southerly wind are representative for a "largescale" monsoon circulation and not a mountain breeze. During the monsoon season, the Aitken mode geometric mean diameter is significantly lower than during the other seasons (Table 1). During the monsoon, new particle formation has been shown to be still rather frequent, despite the low ra- diation levels (Venzac et al., 2008). Hence the small Aitken mode mean geometric diameter possibly indicates the growth of freshly nucleated particles, visible at mid-day Fig. 3. As a result, during night and day, the Aitken mode integrated number concentrations are higher during the monsoon season than during any other season.

In the following section, select nighttime measurements are chosen as representative of the free tropospheric conditions, to study the impact of the different air mass origins on particle concentrations and size distributions.

\subsection{Nighttime number size distributions as a function of the air mass type}

Air masses are classified using a clustering method applied to LAGRANTO (Wernli and Davies, 1997) back-trajectories, as detailed in Bonasoni et al. (2010). The number of air mass backtrajectories belonging to each cluster is shown Table 3. In order to describe the dominant synoptic-scale circulation and to minimize the interference of local valley circulation, only night-time back-trajectories were considered. In Bonasoni et al. (2010), it is shown that SW (SouthWesterly) air masses, representing $23.5 \%$ of all air masses, can be split into three sub-classes according to the statistical analysis: SW-AP (South Westerly-Arabian peninsula), SW-AS (South Westerly-Arabian Sea), and SW-BG (South Westerly- Bengal Gulf). The size distributions observed for the SW-AP and SW-AS sub-classes show sufficient similarities whatever the season to be considered as one single air mass type (SW) in the following discussions. SW-BG air masses occur only during the monsoon season, in replacement of the SW-AP and SW-AS origins and the vertical cross section analysis shows that they originate from lower altitudes.

Westerly air masses, representing most of the air masses (43.3\%), can be also split into three sub-classes: W-NA (Westerly-North Africa), W-EU (Westerly-Europe), and WME (Westerly-Middle East). Aerosols found in the W-NA air masses show similarities with those found in the SW air masses, while European and Middle East aerosols show some discrepancies. 
Regional (Reg) air masses (32.2\%) constitute the third major class of air masses, they differ from other air masses in the fact that they originate at lower altitudes than the other air mass types (except SW-BG air masses which also originate from low altitudes) (Bonasoni et al., 2010). The REG air masses origins spread from the Arabian sea to the gulf of Bengal.

Within one season, significant differences are observed between aerosol size distributions sampled in different air mass types. High nucleation mode integrated concentrations during the post-monsoon season are mostly observed within the SW air masses (Fig. 4). The SW air masses are not more frequent during the post-monsoon season than during the pre-monsoon and winter seasons. Consequently, it is the conjunction of post-monsoon season conditions and SW air masses which promotes nucleation. The SW air masses contain the lowest levels of coarse mode PM (Marinoni et al., 2010), which would explain why, in these air masses, the condensational sink is lower and the occurrence of high levels of radiation during the post-monsoon season triggers nucleation.

The high accumulation mode integrated concentrations during the pre-monsoon season are mostly observed among the W-ME and REG air masses (Fig. 4). In the REG air masses, the high accumulation particle concentrations reflect a larger contribution of the pollution aerosol from down the valley, as observed for other pollution tracers, such as BC, which is rather high during this period in REG air masses (Marinoni et al., 2010). In the case of the W-ME air masses, however, the vertical origin is not different from the other air masses. Thus long distance transport of pollution aerosols seem to impact significantly on the aerosol population during this season, especially when air masses originate from these regions. Also in the other seasons, and especially during the post-monsoon season, Middle East air masses bring high concentrations of accumulation mode particles. In fact, part of these aerosols found in the ME air masses are likely to be submicronic pollution (such as BC, see Bonasoni et al., 2010) or dust, as the coarse mode mass is found to be highest in this air mass as well (day and night altogether) (Marinoni et al., 2010).

During the monsoon season, all air masses contain particles with a dominant Aitken mode and low accumulation mode particle concentrations, except for REG air masses, in which the accumulation mode integrated concentrations remain high. During the monsoon season, nighttime aerosols are efficiently washed out for all sizes above the Aitken mode, while in regional air masses, accumulation mode aerosol concentrations most probably build up rapidly again from pollution originating from lower altitudes, or the activation diameter is larger because of the large concentrations of particles they contain.

During the winter season, differences between different air mass originating aerosol size distributions are mostly observed in the nucleation and Aitken modes. Western air
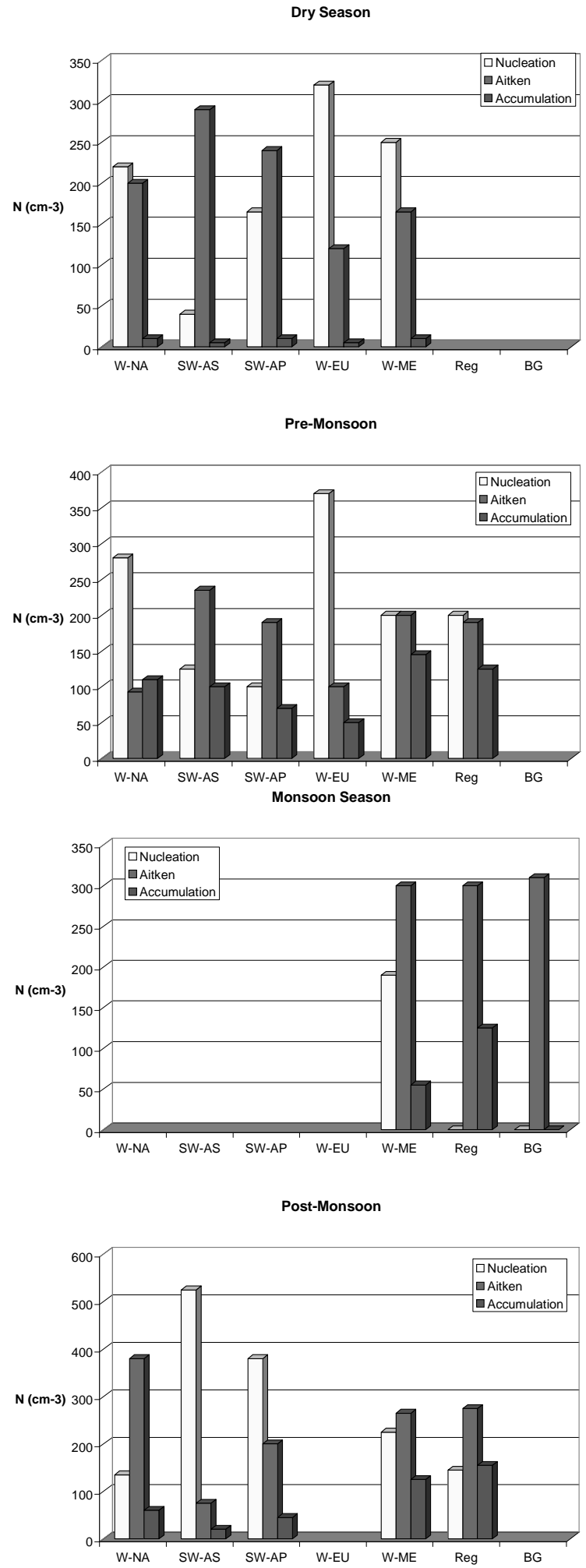

Fig. 4. Contribution of the nucleation, Aitken and accumulation modes integrated number concentrations to the total aerosol number concentration under nighttime conditions for different air mass types for the (a) dry season, (b) pre-monsoon season, (c) monsoon season and (d) post-monsoon season. 
masses contain high nucleation mode integrated concentrations and low accumulation mode integrated particle concentrations, while in the SW air masses the opposite is true. The relationships between air mass origin and aerosol number size distributions are the opposite of those observed during the pre-monsoon and post-monsoon seasons (when nucleation is promoted in SW air masses, while high accumulation mode particle number concentrations are observed in $\mathrm{W}$ air masses). Hence, a single air mass has different characteristics according to the season.

\section{Summary and conclusions}

The present work addresses the diurnal and seasonal variability of aerosol particle total number concentration and aerosol size distributions between $10 \mathrm{~nm}$ and $10 \mu \mathrm{m}$ (from a combination between SMPS and optical particle counter) measured over a two-year period (January 2006-February 2008) at the NCO-P research station (5079 $\mathrm{m}$ a.s.1.).

The annual average number concentration measured over the two-year period at the NCO-P is $860 \mathrm{~cm}^{-3}$. The integrated number concentrations show a strong diurnal variation with maxima during daytime, as observed for all high altitude stations, and for other aerosol characteristics at NCOP (Marinoni et al., 2010; Descesari et al., 2010; Marcq et al., 2010). The daytime maxima are linked to upslope thermal winds, both directly through the transport of pollution aerosols, and indirectly through the formation of new ultrafine particles during transport. These two processes feed the high altitude atmosphere with a contribution which is seasonally variable.

Total concentrations also show a strong seasonality, with maxima during pre-monsoon and post-monsoon seasons and minima during the dry and monsoon season. The dry season minimum is attributed to lower PBL heights involving less air mass export from the lower altitude, while the monsoon minimum is attributed to aerosol scavenging by frequent cloud and rain events. The aerosol concentration maxima are mainly due to new particle formation processes during the post-monsoon season, and the transport of higher levels of pollution aerosols by valley breezes in the form of accumulation mode particles during the pre-monsoon season. Nighttime particle number concentrations (from 03:00 to 08:00 NST) are relatively low throughout the year, indicating the level of free-tropospheric/residual layer background, as a result of down-slope winds during this part of the day. However, the nighttime values follow the daytime concentration seasonal variations, in term of both concentrations and sizes, indicating that the upper troposphere can be fed by thermal winds. In fact, also at Mt Lemmon, Shaw (2007) retains that the aerosols pumped into the free troposphere during the day remain behind at night in residual layers (Shaw et al., 2007). Total nighttime number concentrations are on average two times higher than the ones reported at the Jungfrau- joch station, located in the Swiss Alps at a much lower altitude (3450 ma.s.1.). This result would indicate that up to very high altitudes, the Asian atmosphere is more concentrated with aerosol particles than in Europe.

For the purpose of studying the upper troposphere composition according to different air masses, and the effect of long range transport to the station, nighttime measurements have been analysed as a function of air mass back-trajectories. In this way, the possible interferences of local valley winds were minimized, as confirmed by the lower fraction of accumulation particles with respect to nucleation, and Aitken modes compared with daytime size distribution.

During nighttime, Middle East and regional air masses seem to be responsible for the high accumulation mode particle integrated concentrations during the pre-monsoon season, as obtained by nighttime conditions. Regional air masses originate from lower altitudes, and are probably more influenced by the Asian Brown Cloud than the other air masses, which would explain a more efficient transport of pollution from the Himalayan foothills and Indian Gangetic plains. New particle formation during the post monsoon season is favored under SW air masses, which contain the lowest levels of coarse mode PM.

Acknowledgements. This work was carried out in the framework of the UNEP-ABC (Atmospheric Brown Clouds) and Ev-K2CNR-SHARE (Stations at High Altitude for Research on the Environment) projects. The contribution of CNRS through the PICS bilateral program between CNR and CNRS and LEFEINSU program is greatly acknowledged. The authors are also grateful to Michael Sprenger (ETHZ) for providing LAGRANTO back-trajectories based on ECMWF data. We thank Tenzing Chhottar Sherpa, Kaji Bista, Laxman Adhikary, Pema Sherpa, Lhakpa Tshering Sherpa, Lakpa Tenzi Sherpa, Chhimi Tenzing Sherpa and Hari Shrestha for their support at the Nepal Climate Observatory-Pyramid.

Edited by: J. J. Schauer

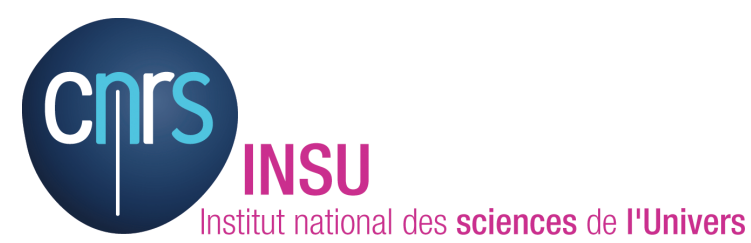

The publication of this article is financed by CNRS-INSU. 


\section{References}

Bollasina, M., Bertolani, L., and Tartari, G.: Meteorological observations at high altitude in Khumbu Valley, Nepal Himalayas, 1994-1999, Bull. Glaciol. Res., 19, 1-11, 2002.

Bonasoni, P., Laj, P., Angelini, F., Arduini, J., Bonafè, U., Calzolari, F., Cristofanelli, P., Decesari, S., Facchini, M. C., Fuzzi, S., Gobbi, G. P., Maione, M., Marinoni, A., Petzold, A., Roccato, F., Roger, J.-C., Sellegri, K., Sprenger, M., Venzac, H., Verza, G. P., Villani, P., and Vuillermoz, E.: The NCO-Pyramid Atmospheric Research Observatory in Himalaya for aerosol, ozone and halocarbon measurements, Sci. Total Environ., 391(2-3), 252-261, doi:10.1016/j.scitotenv.2007.10.024, 2008.

Bonasoni, P., Laj, P., Marinoni, A., Sprenger, M., Angelini, F., Arduini, J., Bonafè, U., Calzolari, F., Colombo, T., Decesari, S., Di Biagio, C., di Sarra, G., Duchi, R., Facchini, M. C., Fuzzi, S., Gobbi, G. P., Maione, M., Panday, A., Roccato, F., Sellegri, K., Verza, G. P., Venzac, H., Villani, P., Vuillermoz, E., and Cristofanelli, P.: Atmospheric Brown Clouds in the Himalayas: first two years of continuous observations at the Nepal Climate Observatory-Pyramid (5079 m), Atmos. Chem. Phys., 10, 75157531, doi:10.5194/acp-10-7515-2010, 2010.

Clarke, A. D., Howell, S., Quinn, P. K., Bates, T. S., Ogren, J. A., Andrews, E., Jefferson, A., Massling, A., Mayol-Bracero, O., Maring, H., Savoie, D., and Cass, G.: INDOEX aerosol: A comparison and summary of chemical, microphysical, and optical properties observed from land, ship, and aircraft, J. Geophys. Res., 107(D19), 8033, doi:10.1029/2001JD000572, 2002.

Cohen, A. J. Anderson, H. R., Ostra, B., Pandey, K. D., Krzyzanowski, M., Künzli, N., Gutschmidt, K., Pope, A., Romieu, I., Samet, J. M., and Smith, K.: The global burden of disease due to outdoor air pollution. Journal of Toxicology and Environmental Health, Part A, 68, 1-7, ISSN: 1528-7394 print, 1087-2620, doi:10.1080/15287390590936166, 2005.

Cristofanelli, P., Bracci, A., Sprenger, M., Marinoni, A., Bonafè, U., Calzolari, F., Duchi, R., Laj, P., Pichon, J. M., Roccato, F., Venzac, H., Vuillermoz, E., and Bonasoni, P.: Tropospheric ozone variations at the Nepal Climate ObservatoryPyramid (Himalayas, $5079 \mathrm{~m}$ a.s.1.) and influence of deep stratospheric intrusion events, Atmos. Chem. Phys., 10, 6537-6549, doi:10.5194/acp-10-6537-2010, 2010.

Hansen, J., Sato, M., Ruedy, R., Lacis, A., and Oinas, V.: Global warming in the twenty-first century: An alternative scenario, PNAS 29 August 2000 97(18), 9875-9880, 2000.

Hyvärinen, A. P., Lihavainen, H., Komppula, M., Sharma, V. P., Kerminen, V. M., Panwar, T. S., and Viisanen, Y.: Continuous measurements of optical properties of atmospheric aerosols in Mukteshwar, northern India, J. Geophys. Res., 114, D08207, doi:10.1029/2008JD011489, 2009.

Kerminen, V.-M., Pirjola, L., and Kulmala, M.: How significantly does coagulational scavenging limit atmospheric particle production?, J. Geophys. Res., 106, 24119-24125, 2001

Kivekäs, N., Sun, J., Zhan, M., Kerminen, V.-M., Hyvärinen, A., Komppula, M., Viisanen, Y., Hong, N., Zhang, Y., Kulmala, M., Zhang, X.-C., Deli-Geer, and Lihavainen, H.: Long term particle size distribution measurements at Mount Waliguan, a highaltitude site in inland China, Atmos. Chem. Phys., 9, 5461-5474, doi:10.5194/acp-9-5461-2009, 2009.

Komppula, M., Lihavainen, H., Hatakka, J., Paatero, J., Aalto, P., Kulmala, M. and Viisanen, Y.: Observations of new parti- cle formation and size distributions at two different heights and surroundings in subarctic area in northern Finland, J. Geophys. Res.-Atmos., 108(D9), 4295, doi:10.1029/2008JD011007, 2003.

Komppula, M., Lihavainen, H., Hyva“ rinen, A.-P., Kerminen, V.-M., Panwar, T. S., Sharma, V. P., and Viisanen, Y.: Physical properties of aerosol particles at a Himalayan background site in India, J. Geophys. Res., 114, D12202, doi:10.1029/2008JD011007. 2009),

Lelieveld, J., Crutzen, P. J., Ramanathan V., et al.: The Indian Ocean Experiment: Widespread Air Pollution from South and Southeast Asia, Science, 291, 1031-1036, 2001.

Mäkelä J. M., Koponen, I. K., Aalto, P., and Kulmala, M.: Oneyear data of submicron size modes of tropospheric background aerosol in southern Finland, J. Aerosol Sci., 31, 595-611, 2000.

Marcq, S., Laj, P., Roger, J. C., Villani, P., Sellegri, K., Bonasoni, P., Marinoni, A., Cristofanelli, P., Verza, G. P., and Bergin, M.: Aerosol optical properties and radiative forcing in the high Himalaya based on measurements at the Nepal Climate Observatory-Pyramid site (5079 m a.s.1.), Atmos. Chem. Phys., 10, 5859-5872, doi:10.5194/acp-10-5859-2010, 2010.

Marinoni, A., Cristofanelli, P. , Calzolari, F., Roccato, F., Bonafè, U., and Bonasoni, P.: Continuous measurements of aerosol physical parameters at the Mt. Cimone GAW Station (2165 masl, Italy), Sci. Total Environ., 391, 241-251, 2008.

Marinoni, A., Cristofanelli, P., Duchi, R., Calzolai, F., Decesari, S., Sellegri, K., Laj, P., Vuillermoz, E., Verza, G. P., and Bonasoni, P.: Aerosol mass and black carbon concentrations, two yearround observations at NCO-P (5079 m, Southern Himalayas), Atmos. Chem. Phys., 10, 8551-8562, doi:10.5194/acp-10-85512010, 2010.

Nakajima, T., Yoon, S., Ramanathan, V., Shi, G., Takemura, T., Higurashi, A., Takamura, T., Aoki, K., Sohn, B., Kim, S., Tsuruta, H., Sugimoto, N., Shimizu, A., Tanimoto, H., Sawa, Y., Lin, N., Lee, C., Goto, D., and Schutgens, N.: Overview of the Atmospheric Brown Cloud East Asian Regional Experiment 2005 and a study of the aerosol direct radiative forcing in east Asia, J. Geophys. Res., 112, D24S91, doi:10.1029/2007JD009009, 2007.

Nishita, C., Osada, K., Matsunaga, K., and Iwasaka, Y.: Number-size distributions of free tropospheric aerosol particles at Mt. Norikura, Japan: Effects of precipitation and air mass transportation pathways, J. Geophys. Res., 112, D10213, doi:10.1029/2006JD007969, 2007.

Nyeki S., Li, F., Weingartner, E., Streit, N., Colbeck, I., Gäggeler, H. W., and Baltensperger, U.: The background aerosol size distribution in the free troposphere: An analysis of the annual cycle at a high-alpine site, J. Geophys. Res. 103, 31749-31762, 1998.

Osada K., Kido, M., Iida, H., Matsunaga, K., Iwasaka, Y., Nagatani, M., and Nakada, H.: Seasonal variation of free tropospheric aerosol particles at Mt. Tateyama, central Japan, J. Geophys. Res.-Atmos., 108(D23) 8667, doi:10.1029/2003JD003544, 2003.

Panday A. K. and Prinn R. G.: Diurnal cycle of air pollution in the Kathmandu Valley, Nepal: Observations, J. Geophys. Res., 114, D09305, doi:10.1029/2008JD009777, 2009.

Pio, C. A., Legrand, M., Oliveira, T., Afonso, J., Santos, C., Caseiro, A., Fialho, P., Barata, F., Puxbaum, H., Sanchez-Ochoa, A., Kasper-Giebl, A., Gelencsér, A. Preunkert, S., and Schock, M.: Climatology of aerosol composition (organic versus inorganic) at nonurban sites on a west-east transect across Europe, J. 
Geophys. Res., Vol. 112, D23S02, doi:10.1029/2006JD008038, 2007

Raes F., Van Dingenen, R, Cuevas, E., Van Velthoven, P. F. J., and Prospero, J. M.: Observation of aerosols in the free troposphere and marine boundary layer of the subtropical Northeast Atlantic: discussion of processes determining their size distribution, J. Geophys. Res., 102(N17), 21315-21328, 1997

Ramanathan, V., Krutzen, P. J., Kiehl, J. T., and Rosenfeld, D.: Aerosols, climate, and the hydrology, Science, 294, 2119-2124, 2001.

Ramanathan, V., Chung, C., Kim, D., Bettge, T., Buja, L., Kiehl, J. T., Washington, W. M., Fu, Q., Sikka, D. R., and Wild, M.: Atmospheric Brown Clouds: Impacts on South Asian Climate and Hydrological Cycle, PNAS, 102(15), 5326-5333, 2005.

Ramanathan, V., Ramana, M. V., Roberts, G., Kim, D., Corrigan, C., Chung, C., and Winkle, D.: Warming trends in Asia amplified by brown cloud solar absorption, Nature, 448, 575-578, 2007 a.

Ramanathan, V., Li, F., Ramana, M. V., Siva, P. S., Kim, D., Corrigan, C. E., Nguyen, H., Stone, E. A., Schauer, J. J., Carmichael, G. R., Adhikary, B., and Yoon, S. C.: Atmospheric Brown Clouds: Hemispherical and regional variations in long range transport, absorption and radiative forcing, J. Geophys. Res., 112, D22S21, 26 pp., doi:10.1029/2006JD008124, 2007b.

Ramanathan, V., Agrawal, M., Akimoto, H., et al.: Atmospheric Brown Clouds: Regional Assessment Report with Focus on Asia, Published by the United Nations Environment Programme, Nairobi, Kenya, 2008.

Richter, A., Burrows, J. P., Nüß, H., Granier, C., and Niemeier, U.: Increase in tropospheric nitrogen dioxide over China observed from space, Nature, 437, 129-132, 2005.

Shaw, E.: Aerosols at a mountaintop observatory in Arizona, J. Geophs. Res., 112, D07206, doi:10.1029/2005JD006893, 2007.

Spracklen, D. V., Carslaw, K. S., Merikanto, J., Mann, G. W., Reddington, C. L., Pickering, S., Ogren, J. A., Andrews, E., Baltensperger, U., Weingartner, E., Boy, M., Kulmala, M., Laakso, L., Lihavainen, H., Kivekäs, N., Komppula, M., Mihalopoulos, N., Kouvarakis, G., Jennings, S. G., O’Dowd, C., Birmili, W., Wiedensohler, A., Weller, R., Gras, J., Laj, P., Sellegri, K., Bonn, B., Krejci, R., Laaksonen, A., Hamed, A., Minikin, A., Harrison, R. M., Talbot, R., and Sun, J.: Explaining global surface aerosol number concentrations in terms of primary emissions and particle formation, Atmos. Chem. Phys., 10, 4775-4793, doi:10.5194/acp-10-4775-2010, 2010.

Tunved, P., Hansson, H.-C., Kulmala, M., Aalto, P., Viisanen, Y., Karlsson, H., Kristensson, A., Swietlicki, E., Dal Maso, M., Strm, J., and Komppula, M.: One year boundary layer aerosol size distribution data from five nordic background stations, Atmos. Chem. Phys., 3, 2183-2205, doi:10.5194/acp-3-2183-2003, 2003.
Tunved, P., Nilsson, E. D., Hansson, H.-C., and Ström, J.: Aerosol characteristics of air masses in northern Europe: Influences of location, transport, sinks, and sources, J. Geophys. Res. 110, D07201, doi:10.1029/2004JD005085, 2005.

Van Dingenen, R., Putaud, J.-P., Martins-Dos Santos, S., and Raes, F.: Physical aerosol properties and their relation to air mass origin at Monte Cimone (Italy) during the first MINATROC campaign, Atmos. Chem. Phys., 5, 2203-2226, doi:10.5194/acp-52203-2005, 2005.

Venzac, H., Sellegri, K., and Laj, P.: Nucleation events detected at the high altitude site of the Puy de Dôme Research Station, France, Boreal Environ. Res., 12, 345-359, 2007.

Venzac, H., Sellegri, K., Laj, P., Villani, P., Bonasoni, P., Marinoni, A., Cristofanelli, P., Calzolari, F., Fuzzi, S., Decesari, S., Facchini, M.-C., Vuillermoz, E., and Verza, G. P.: High Frequency New Particle Formation in the Himalayas, PNAS, 105(41), 15666-15671, 2008.

Venzac, H., Sellegri, K., Villani, P., Picard, D., and Laj, P.: Seasonal variation of aerosol size distributions in the free troposphere and residual layer at the puy de Dme station, France, Atmos. Chem. Phys., 9, 1465-1478, doi:10.5194/acp-9-1465-2009, 2009.

Villani, P., Picard, D., Michaud V., et al.: Design and Validation of a Volatility Hygroscopic Tandem Differential Mobility Analyzer (VH-TDMA) to Characterize the Relationships Between the Thermal and Hygroscopic Properties of Atmospheric Aerosol Particles, Aerosol Sci. Technol., 42(9) 729-741, 2008.

Weingartner, E., Nyeki, S., and Baltensperger, U.: Seasonal and diurnal variation of aerosol size distributions $(10<D<750 \mathrm{~nm})$ at a high-alpine site Jungfraujoch (3580 m asl), J. Geophys. Res., 104, 26809-26820, 1999.

Whitby, K. T.: The physical characteristics of sulphur aerosols, Atmos. Environ., 12, 135-159, 1978.

Yasunari, T. J., Bonasoni, P., Laj, P., Fujita, K., Vuillermoz, E., Marinoni, A., Cristofanelli, P., Duchi, R., Tartari, G., and Lau, K.-M.: Preliminary estimation of black carbon deposition onto snow surface from NCO-P data and its possible impact on snow albedo changes over Himalayan glaciers during the pre-monsoon season, Atmos. Chem. Phys., 10, 6603-6615, 2010,

http://www.atmos-chem-phys.net/10/6603/2010/. 